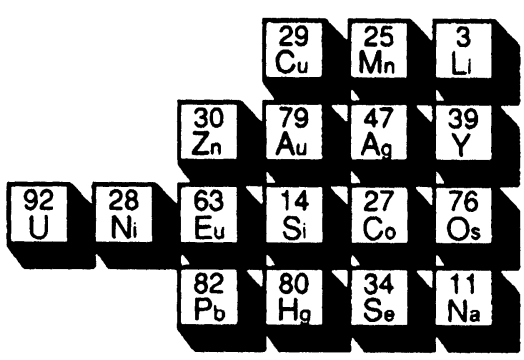

TRACE ELEMENT - INSTITUTE FOR UNESCO International Center for Trace Element Study created under the auspices of UNESCO

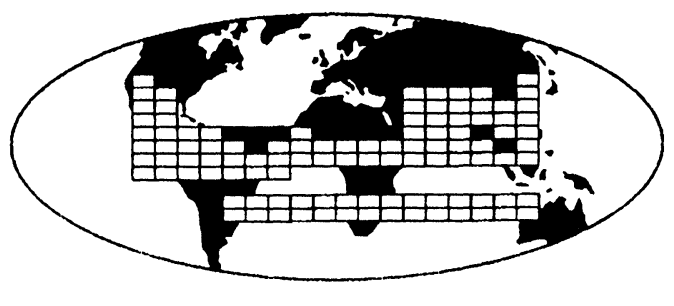

ISTERH

International Society for Trace Element

Research in Humans

\title{
Vth CONFERENCE of the INTERNATIONAL SOCIETY FOR TRACE ELEMENT RESEARCH IN HUMANS (ISTERH)
}

\author{
Lyon, France \\ September 27 - 30th 1998
}

The Fifth International Conference of the ISTERH will be held at "Trace Element-Institute for UNESCO" in Lyon, France. The Conference will be sponsored by the Institute and by other local and international organizations. The programme will be multidisciplinary and will consist of invited papers, workshops, oral presentations

and poster sessions. Topics will include the influence of trace elements on gene expression, the effects of reactive oxygen species on human health and disease, and the newer aspects of essential and toxic trace elements.

Attention will also be focused on the impact of trace elements in developing countries with special emphasis on metal toxicity associated with rapid industrial development in the regions of Asia, Africa and Latin America.

The meeting will be of interest to all scientists involved in trace element research. All accepted abstracts will be published in the official journal of the Society, "The Journal of Trace Elements in Experimental Medicine".

For more information, contact:

Vth CONFERENCE OF THE INTERNATIONAL SOCIETY

FOR TRACE ELEMENT RESEARCH IN HUMANS, September 27 - 30th 1998

TRACE ELEMENT - INSTITUTE FOR UNESCO

Immeuble Le Condorcet,

1 place de l'Ecole

B.P. 7021 - F-69342 Lyon Cedex 07, France

Tel. 33 (0) 472808290 I Fax 33 (0) 478588671

E-mail: 101711.2322 @ compuserve.com 